\title{
Spiritual Communion in Mystical Texts from the Twelfth to the Sixteenth Centuries
}

Ineke Cornet

\section{Abstract}

Since around the twelfth century, spiritual communion was defined as participating in the sacrament in a spiritual manner. This practice was based on Augustine's distinction between the sacrament and the substance of the sacrament, which is spiritual union with Christ. Mystics such as William of Saint-Thierry contributed greatly to this practice, as they focused on the personal dimension of a spiritual union with Christ. Spiritual communion can take place when one is hindered from partaking in the sacrament, through meditation on Christ's sacrifice or through watching the Eucharistic celebration. Yet, for mystics, spiritual communion is also the continual, inner celebration of the substance of the sacrament, which allowed them to harmoniously combine sacramental communion and spiritual communion. Spiritual communion is referred to by many mystics, including Gertrude of Helfta, Tauler, and the Evangelical Pearl. After the Council of Trent started to promote sacramental communion, the practice of spiritual communion declined.

\section{Keywords}

Spiritual communion, liturgical mysticism, Eucharist, medieval mysticism, Low Countries

The current COVID-19 pandemic has stimulated a reflection on the different ways the sacrament of the Eucharist, or the Lord's Supper, can be celebrated. New online possibilities have led many to ask the question of whether and how the sacrament can be celebrated at home. Various positions have been taken on this issue, ranging from fasting from the sacrament, distributing consecrated hosts to parish members, or online celebrations during which one prepares bread and wine at home. Several Churches, including Roman Catholic and Anglican Churches, have encouraged the practice of spiritual communion. ${ }^{1}$ Since the high Middle Ages, the Church has distinguished explicitly between two ways

I am grateful to Satoshi Kikuchi, Arjan Plaisier, Maarten Wisse and Anne-Marie Bos O. Carm for their critical reading of earlier versions of this article. I also thank my colleagues Charles Caspers, Ad de Keyzer, and Ad Poirters for their literature suggestions.

1) Other articles in this yearbook examine the range of current practices. Pope Francis, for example, has regularly referred to the practice of spiritual communion. On the position of the Church of England, see the "Guidance on Spiritual Communion and Coronavirus (COVID-19)" at www.churchofengland.org. 
of receiving the sacrament: firstly, sacramental communion, which includes the aspect of spiritual communion as the sacrament brings forth spiritual benefits and inner union with Christ, and secondly, spiritual communion, that is, spiritual union with Christ without sacramental communion. This spiritual communion was understood as participating inwardly in the sacrament of the Eucharist, while not being able to or choosing not to partake sacramentally, although often combined with a longing for sacramental communion. ${ }^{2}$ Reasons for this could vary from being physically unable to come to church or being too sick to eat, to an interdict on the region or monastery that meant either all celebrations were suspended or some groups were not allowed to communicate. Fear of being unworthy of participating in the sacrament is regularly mentioned as well. Spiritual communion is based on the distinction between the sacrament and the substance of the sacrament. Union with Christ was often understood as the substance of the sacrament that could also be attained without the sacrament. Spiritual communion could happen through looking either at the host during the celebration, particularly at the moment of the elevation, or at the reserved sacrament kept in the church. For some mystics, spiritual communion could take place through pondering Christ's redemptive suffering, even without being near the consecrated bread or the celebration of the sacrament, though it was always understood as an extension of sacramental communion, and not opposed to it.

Mystical texts focusing on the spiritual meaning of the liturgy outline that, because God dwells within the person, the substance of the liturgy in general and the substance of the sacrament in particular are also accessible and celebrated within the spirit of the person. Mystical texts make a close connection between the liturgy and mysticism. Even though mystical experiences are private, dynamic, and experienced as gifts from God, which one cannot fully prepare for or schedule, they are nevertheless still connected to the liturgy. The liturgy functions as an intermediary through which the person reaches spiritual experiences. Though the nature of liturgy is quite the opposite of the mystical - it is a public celebration that is structured and planned, formalized and cyclical, full of rituals and symbols, and filled with spoken words in alternation with silence - it is nevertheless imbued with spiritual experiences. ${ }^{3}$ Many mystical authors describe the liturgical aspects of their mystical life, though these are

2) Louis de Bazelaire, "Communion spirituelle," in Dictionnaire de Spirituelité ascétique et mystique 2 (Paris: Beauchesne, 1953), 1294. Sometimes, sacramental communion without any spiritual benefit is mentioned as well, of which Judas, who betrayed Jesus, is the main example.

3) David W. Fagerberg, Liturgical Mysticism (Steubenville, OH: Emmaus Academic, 2019), 1-21; Bernard McGinn, The Growth of Mysticism. Gregory the Great through the Twelfth Century, The Presence of God. A History of Western Christian Mysticism, vol. 2 (New York: Crossroad, 1994), 56; Pamela E. Klassen, "Ritual," in The Oxford Handbook of Religion and Emotion, ed. John Corrigan (Oxford: Oxford University Press, 2007), 14369. 
not always experiential or autobiographical. ${ }^{4}$ For many mystics, spiritual communion is closely linked to the liturgy of the sacrament of the Eucharist.

The first section of this article outlines the distinction between sacrament and the substance of the sacrament in Augustine, which informed the medieval practice of spiritual communion. It also explores medieval liturgical and theological developments that supported the practice of spiritual communion. The second section analyzes mystical authors from the Low Countries and neighboring Germany, starting with one of the first mystical theologians to address this theme in greater depth in the beginning of the twelfth century, William of Saint-Thierry. The third section traces how spiritual communion was spread among mystics from the thirteenth century onwards. The fourth section concludes with mystical texts from the sixteenth century. After the Council of Trent decided in favor of sacramental communion, the practice of spiritual communion declined.

\section{Origins of the medieval concept of spiritual communion}

The earliest liturgical and theological texts on the Eucharist do not refer to the practice of spiritual communion. And yet the heart of the medieval distinction between sacramental and spiritual communion can be traced back to aspects of Augustine's theology. Augustine distinguished between the sacrament (sacramentum) and that to which the sacrament points (the res or virtue of the sacrament), which is Christ. ${ }^{5}$ In his commentaries on John 6:55, Augustine explains that eating Christ's flesh and drinking his blood are not only a matter of eating, but of participating in Christ. His famous words of not eating Christ with one's teeth but with one's heart would resonate throughout the medieval period:

The real Christ is in the Word and in flesh.... This, then, is the bread that comes down from heaven, that one may eat of it and not die. But this is what belongs to the virtue of the sacrament, not to

4) Joseph Gelineau, "Liturgie. Approaches Doctrinales," in Dictionnaire de spiritualité ascétique et mystique. Doctrine et histoire, vol. 11, eds. André Rayez, André Derville, and Aimé Solignac (Paris: Beauchesne, 1976), 92327; Cyprian Vagaggini, Theological Dimensions of the Liturgy. A General Treatise on the Theology of the Liturgy, trans. Leonard J. Doyle and W. A. Jurgens (Collegeville, MN: The Liturgical Press, 1976), 716-38; Irénée-H. Dalmais, “Liturgie. Problèmes théologiques," in Dictionnaire de Spiritualité Ascétique et Mystique. Doctrine et Histoire, vol. 11, eds. André Rayez, André Derville, and Aimé Solignac (Paris: Beauchesne, 1976), 932-39; Nicolaus Largier, "Medieval Mysticism," in The Oxford Handbook of Religion and Emotion, ed. John Corrigan (Oxford: Oxford University Press, 2007), 364-79, 367; Rob Faesen, "What is a Mystical Experience? History and Interpretation," Louvain Studies 23 (1999): 221-45; Bernard McGinn, The Foundations of Mysticism, The Presence of God. A History of Western Christian Mysticism, vol. 1 (New York: Crossroad, 1991), 64.

5) Bazelaire, "Communion spirituelle," 1296-97. 
the visible sacrament; he that eats within, not without; who eats in his heart, not who presses with his teeth. ${ }^{6}$

Augustine explicitly mentions that eating Christ is eating Christ within, not merely eating him "with the teeth." The inner union with Christ is the virtue of the sacrament, though Augustine does not yet separate it from sacramental communion, but connects it to eating the sacrament in a worthy manner. Those who eat Christ are worthily participating in the sacramental communion; those who do not dwell in Christ may participate in sacramental communion but without receiving the spiritual benefits of union with Christ:

To eat this flesh and to drink that drink is to dwell in Christ, and to have Christ dwelling within. Consequently, he who does not dwell in Christ, and in whom Christ does not dwell, doubtless neither eats His flesh nor drinks His blood, but rather he eats and drinks the sacrament of so great a thing to his own judgment. ${ }^{7}$

Augustine uses the example of Judas to illustrate the need for spiritual communion when participating in the sacrament. He explains that Judas ate the sacramental bread to his own judgment since he betrayed Christ. $^{8}$

Augustine distinguishes between the outer, material side of the sacrament and the inner dimension, which remains eternally, to illustrate the spiritual, inner dimension of the sacrament: "Whatever you see, will disappear, but the invisible which it signifies, does not pass away but will remain." 9 This inner dimension is Christ, with whom the Church is united. Augustine equates faith in Christ with eat-

6) Augustine, Tractates on the Gospel of John, ed. Kevin Knight, trans. by John Gibb, Nicene and PostNicene Fathers (Buffalo, NY: Christian Literature Publishing Co, 1888), Tractate 26.12. Translation quoted with adaptations. Cf. Aurelius Augustinus, In lohannis evangelium tractatus, ed. Radbodus Willems, Corpus Christianorum Series Latina, vol. 36 (Turnhout: Brepols, 1954). "verus Christus in Verbo et in carne ... Hic est ergo panis de coelo descendens, ut si quis manducaverit ex ipso, non moriatur. Sed quod pertinet ad virtutem Sacramenti, non quod pertinet ad visibile Sacramentum: qui manducat intus, non foris; qui manducat in corde, non qui premit dente."

7) Augustine, Tractates on the Gospel of John, Tractate 26.18. Translation quoted with adaptations. Cf. Augustinus, In lohannis evangelium tractatus. "Hoc est ergo manducare illam escam, et illum bibere potum, in Christo manere, et illum manentem in se habere. Ac per hoc qui non manet in Christo, et in quo non manet Christus, procul dubio nec manducat carnem eius, nec bibit eius sanguinem, sed magis tantae rei Sacramentum ad iudicium sibi manducat et bibit."

8) Augustine, Tractates on the Gospel of John, Tractate 26.11.

9) Augustine, "Sermones de Tempore," in Opera Omnia Augustini Hipponensis, Patrologia Latina 38 (Paris: Beauchesne), Sermo 227, in die paschae IV, 1101. "Quod vides, transit: sed quod significatur invisibile, non transit; sed permanet." 
ing: "to believe ... in him is to eat the living bread."10 It is clear from his treatise that Augustine never pits spiritual union with Christ against sacramental communion. ${ }^{11}$ The spiritual dimension of the sacrament is that which takes place inwardly in those who receive. To those who receive communion, he writes that "if you are the body of Christ and his members, then your secret is on the table of the Lord, and you receive your secret." 12 His statement that we may become what we receive would become a topos in western Eucharistic thinking. ${ }^{13}$ Augustine's inner dimension of the sacrament is embedded in his view on the inner dimension of the liturgy. Though there is no systematic reference to this concept, Augustine does mention that the feast of Easter is celebrated continually within one's heart. ${ }^{14}$ This is also a theological concept that is reflected in medieval mystical theology on the continuing nature of spiritual communion once the moment of sacramental communion has passed.

Augustine's references to the spiritual dimension of the sacrament were used by medieval theologians to explain their theology and practice of spiritual communion. In addition, several other factors contributed to the development of the concept of spiritual communion in the Western Church. The first of these were the Eucharistic Controversies and scholastic discussions on the nature and efficacy of the Eucharist. In the eighth century, the introduction of the Roman Rite by the Carolingians led to debates on how to interpret the Roman Missal. ${ }^{15}$ Ratramnus maintained that Christ was present in figura, whereas Paschasius Radbertus stated that Christ was present in veritate. ${ }^{16}$ Paschasius' view became dominant. The debate, however, resurfaced during the second Eucharistic Controversy. Berengarius of Tours (ca. 999-1088) pleaded again for a more symbolic understanding of the nature of the body of Christ in the Eucharist. Several theologians defended Paschasius' position and wrote treatises on the true presence of Christ, including the later Pope Alexander III, who defined the theology of

10) Augustine, Tractates on the Gospel of John, 26.1. Translation quoted with adaptations. Cf. Augustinus, In Iohannis evangelium tractatus. "Credere ... in eum, hoc est manducare panem vivum."

11) Heinz Robert Schlette, Die Lehre von der geistlichen Kommunion bei Bonaventura, Albert dem Grossen und Thomas von Aquin (Munich: Max Huebner, 1959), 9-10.

12) Augustine, "Sermones de Tempore," Sermo 272 in die pentecostis, 1247. "Vos autem estis corpus Christi, et membra (I Cor. XII, 27). Si ergo vos estis corpus Christi et membra, mysterium vestrum in mensa Dominica positum est: mysterium vestrum accipitis."

13) Ad de Keyzer, "Um zu werden wer wir sind. Mystagogische Aspekte der Eucharistie," in Seeing the Seeker. Explorations in the Discipline of Spirituality. a Festschrift for Kees Waaijman on the Occasion of His 65th Birthday, eds. Hein Blommestijn and Rijcklof Hofman (Leuven: Peeters, 2008), 595-608.

14) Augustine, Sermo Wilmart 9 , quoted in J. Hermans, Uw geheim ligt op de tafel des Heren. De Eucharistie in oud-christelijke geschriften (Tabor: Brugge, 1982), 116.

15) See, for example, the works by Amalar of Metz on the liturgy.

16) Charles Caspers, De Eucharistische vroomheid en het feest van Sacramentsdag in de Nederlanden tijdens de Late Middeleeuwen, Miscellanea Neerlandica, vol. 5 (Leuven: Peeters, 1992), 11-16; Guerric Aerden, “Inleiding," in Willem van St. Thierry - Geloofsgeheim (Eindhoven: Damon, 2019), 18-23. 
the transubstantiation, which would be commonly accepted after Lateran IV in $1215 .{ }^{17}$ These debates on the Eucharist encouraged Eucharistic piety. The bridal mysticism of William of Saint-Thierry, on which the next section focuses, was fused with Eucharistic piety. ${ }^{18}$ Theologians not only reflected on the nature of the sacrament, but also on the efficacy of the sacrament and the inner disposition. Aquinas focused so much on the change of the bread into the body of Christ that it outweighed the need for the right attitude. ${ }^{19}$ It is therefore not surprising that, for him, spiritual communion without the sacrament is inferior to sacramental communion. If this is the only option, however, one's desire for the sacrament will still confer the benefits to the believer: "one receives the effect of this sacrament, whereby a man is spiritually united with Christ through faith and charity.... The effect of the sacrament can be secured by every man if he receive it in desire, though not in reality." ${ }^{20}$ Other theologians, like Bonaventure, Hugh of St. Victor and William of Saint-Thierry in his Sacrament of the Altar, argued that not only the real presence of Christ matters, but also the spiritual side of faith and love. Without the right disposition, the sacrament would not be beneficial. They thus contributed to the concept of spiritual communion, understood as both the spiritual side of the sacrament as well as a practice independent of sacramental communion. For them, spiritual communion was not inferior to sacramental communion, though it was not pitted against sacramental communion. ${ }^{21}$

A second factor contributing to the development of the concept of spiritual communion in the Western church consists of a new focus on the moment of consecration and the elevation of the host. Stimulated by the growing emphasis on the theology of the real presence - as advocated by, for example, Anselm of Laon (d. 1117) and William of Champaux (d. 1121), and partially in response to Cathar movements that denied the presence of Christ in the bread - elevation was used to affirm the pres-

17) Caspers, Eucharistische vroomheid, 16-19. On transubstantiation, see Henricus Denzinger and Adolfus Schönmetzer, Enchiridion Symbolorum. Definitionum et declarationum de rebus fidei et morum, trans. Peter Hünermann, 32nd ed. (Freiburg im Breisgau: Herder, 2012), 430.

18) Charles Caspers, "Late Medieval Liturgy and Its Inner Tension: The hermeneutic significance of Thomas à Kempis's Devota exhortatio ad sacram communionem," in What is "Theology" in the Middle Ages? Religious Cultures of Europe (11th-15th Centuries) as Reflected in their Self-Understanding, ed. Mikołaj Olszewski (Münster: Aschendorff, 2007), 383.

19) On the role of Eucharistic theology and the controversies between Aquinas and, for example, Bonaventure, see Gary Macy, "Theology of the Eucharist in the High Middle Ages," in A Companion to the Eucharist in the Middle Ages, eds. Ian Christopher Levy, Gary Macy, and Kristen van Ausdall (Leiden: Brill, 2012), 365-98.

20) Thomas Aquinas, Summa Theologiae, Part III, Question 80: "The use or receiving of this sacrament in general," article 1. Translated by Fathers of the English Dominican Province. Online Edition Copyright @ 2017 by Kevin Knight, https://www.newadvent.org/summa/4080.htm\#article1.

21) Macy, "Theology of the Eucharist in the High Middle Ages," 365-98; Joseph A. Jungmann, The Mass of the Roman Rite. Its Origins and Developments (Missarum Sollemnia), trans. Francis A. Brunner (New York: Benzinger, 1951), 121-22. On spiritual communion as such, see Schlette, Die Lehre von der geistlichen Kommunion. 
ence of Christ in the consecrated bread and evoke reverence. ${ }^{22}$ The practice of elevation spread early on in Cistercian monasteries in the twelfth century and was widely known in the Western Church in the thirteenth century. For many lay people, the elevation became quite important and often replaced sacramental communion. Many mystics also refer to spiritual communion at this moment of elevation, encouraged by Hugh of St. Victor, for example. ${ }^{23}$

A third factor that encouraged reverence for the sacrament were new rituals for receiving the final communion (viaticum) from around 1100 onwards. For this, the Apostolic Creed that the dying person recited was replaced by the Eucharistic Creed, with which one affirmed the real presence of Christ in the Eucharist. In addition, whenever a host was brought from the Church to a dying person, a procession would accompany the host. A reverent response would include bowing before the sacrament for all those who saw the procession. This is strongly linked to the fourth factor, which are other processions with the sacrament, not just for the procession with the viaticum. This includes the procession on the feast day of Corpus Christi, instituted by Pope Urban IV in 1264 with the bull Transiturus de hoc mundo. ${ }^{24}$

Fifth, the impact of the devotional practices of beguines and mystics should not be underestimated. Many described a desire for frequent sacramental communion, at least once a week. Many also referred to spiritual communion in addition to this. ${ }^{25}$ Lastly, spiritual communion flourished, not only out of reverence and mystical love, but also out of fear of receiving the sacrament unworthily. Particularly from the fourteenth century onwards, spiritual communion without sacramental communion became common. The laity in particular resorted to spiritual communion and abstained from sacramental communion. ${ }^{26}$

22) Jungmann, The Mass of the Roma Rite. Its Origins and Developments (Missarum Sollemnia), 119-22. On the development from the Early Church to the Middle Ages, see Peter Browe, Die Eucharistie in Mittelalter. Liturgiehistorische Forschungen in kulturwissenschaftlicher Absicht (Münster: LIT, 2011), 475-508.

23) Caspers, Eucharistische vroomheid, 20-24; Gary Macy, The Theologies of the Eucharist in the early Scholastic Period. A study of the salvific function of the sacrament according to the theologians, c. 1080-c. 1220 (Oxford: Clarendon, 1984), 147-48. On the origins of elevation, see particularly Browe, Die Eucharistie in Mittelalter.

24) Caspers, Eucharistische vroomheid, 22-24, 81-94. On the viaticum and processions with the sacrament, see Browe, Die Eucharistie in Mittelalter, 42-55, 115-72, 459-74.

25) Caspers, Eucharistische vroomheid, 38-41.

26) Miri Rubin, Corpus Christi. The Eucharist in Late Medieval Culture (Cambridge: Cambridge University Press, 2002), 150-56; Charles Caspers, "Geert Grote und sein Ruf als Malleus haereticorum," Archa Verbi. Yearbook for the Study of Medieval Theology 15 (2018): 145; Jungmann, The Mass of the Roma Rite. Its Origins and Developments (Missarum Sollemnia), 120-22. 


\section{William of Saint-Thierry and twelfth-century mystical theology on spiritual communion}

The mystical theologian William of Saint-Thierry (ca. 1085-1148), friend of Bernard of Clairvaux and known for his mystical exegesis of the Song of Songs, plays an important role in the development of the concept of spiritual communion. He is one of the first authors to describe it elaborately. ${ }^{27} \mathrm{His}$ works are embedded in the debates on the nature of the Eucharist that led up to defining the doctrine of transubstantiation in 1215. William, building on the work of Lanfranc of Bec (d. 1098), defended the real presence of the body and blood in the sacrament in his treatise On the Sacrament of the Altar (De sacramento altaris) around 1127/1128. William's originality lies in paying attention to the right spiritual attitude of receiving the sacrament, so that one truly receives the sacrament to one's spiritual benefit. ${ }^{28}$ William points out that receiving the sacrament can only bear fruit if one receives this "with a fiery faith working through love." ${ }^{29}$ He argues that one should not doubt that Christ is truly present on the altar; yet, it will only bring benefit to those who receive it with "bonds of enjoying affection." 30 The effect of the sacrament is closely related to the affection of the person. The more one loves, the more one enjoys the sacrament; and the more one eats the sacrament, the more one loves Christ. William thus closely connects Eucharistic piety to love for Christ. ${ }^{31}$

William stresses that one should participate in sacramental communion whenever possible. ${ }^{32}$ In Citeaux, mother house of the Cistercian order he later joined, the Eucharist was celebrated daily, twice a day on Sundays and feast days. ${ }^{33}$ Though he focuses on sacramental communion, William emphasizes the spiritual communion with Christ (the res of the sacrament) to the point that, according to him, it can be consumed even without sacramental communion. Every baptized person who is part of Christ's body (the church) participates in the substance of the sacrament, even if a person died before being able to physically receive the sacrament, as a baptized person can never lose the reality to which this sacrament points. ${ }^{34}$ Nevertheless, in his Sacrament of the Altar, William emphasizes spiritual communion as an aspect of sacramental communion. William quotes Augustine to state that what really matters is union with Christ:

\footnotetext{
27) Caspers, Eucharistische vroomheid, 24. fide ardente quae per dilectionem operator."

30) William of Saint-Thierry, 353. "per piae dilectionis affectum."

31) William of Saint-Thierry, 352-53.

32) William of Saint-Thierry, 354-55.

33) Aerden, "Inleiding," 30-34.

34) William of Saint-Thierry, De sacramento altaris, 355.
}

28) Brian Patrick McGuire, "A Chronology and Biography of William of Saint-Thierry," in A Companion to William of Saint-Thierry, ed. F. Tyler Sergent (Leiden: Brill, 2019), 20; Aerden, “Inleiding," 18-26.

29) William of Saint-Thierry, De sacramento altaris, Patrologia Latina, vol. 180 (Paris: Migne, 1853), 352. "cum 
He [Christ] is the bread that came down from heaven.... But this concerns the power of the sacrament, not the visible form of the sacrament. What matters is a person who eats inwardly, not outwardly; a person who eats with his heart, and not a person who bites with his teeth. 35

William concludes his On the Sacrament of the Altar with an exhortation to receive the sacrament: "to eat the spiritual body of Christ in a spiritual way, in the sacrament of his true body." 36

In his Golden Epistle, written to the Carthusians of Mont-Dieu in 1144, William further explains spiritual communion as a practice that can continually take place inwardly. At the heart of his concept is an inner celebration of the liturgy based on God's indwelling the soul. Whoever is in his inner cell is actually also in heaven; whoever practices "continual remembrance of God" is able to "enjoy God in himself and himself in God." 37 The inner cell is the place where God dwells with the spirit of the human person. ${ }^{38}$ William states that the eternal liturgy that takes place in heaven (coelis) also takes place in the cells of the monks (cellis):

In a church at certain times the sacraments of the Christian faith are celebrated in a visible and symbolic way. But in the cells as in heaven the reality of all sacraments of our faith is constantly celebrated with as much truth, in the same order, although not yet with the same pure majesty and the same assurance that marks eternity. 39

Based on this principle, William describes a number of spiritual practices, including spiritual communion. Here, spiritual communion is a pure inner practice in one's cell, for which one does not need to be in the presence of the sacrament. William encourages one to recollect the benefits of Christ's suffering and redemption by devoting

35) William of Saint-Thierry, 357. "Hic est ergo panis de coelo descendens ... sed quod pertinet ad virtutem sacramenti, non quod pertinet ad visibile sacramentum. Qui manducat intus, non foris; qui manducat corde, non qui premit dente."

36) William of Saint-Thierry, 358. "et spiritualem carnem Jesu spiritualiter manducare, in sacramento verae ejus carnis."

37) William of Saint Thierry, The Golden Epistle, trans. Theodere Berkeley (Kalamazoo, MI: Cistercian Publications, 1971), IX.27. Cf. William of Saint-Thierry, “Epistola ad Fraters de Monte Dei (Epistola Aurea)," ed. Jacques Paul Migne, Patrologia Latina 184 (Paris: Migne, 1902), 313. “Dei memoria continua; ad fruendum Deo in se, et se in Deo."

38) William of Saint-Thierry, "Epistola ad Fraters de Monte Dei (Epistola Aurea)," 325. "interior est conscientia tua, quam inhabitare debet omnium interiorum tuorum interior Deus, cum spiritu tuo."

39) William of Saint-Thierry, The Golden Epistle, XI.36. Cf. Saint-Thierry, "Epistola ad Fraters de Monte Dei (Epistola Aurea)," 314. "In templo visibiliter et figurative aliquando christianae pietatis sacramenta dispensantur: in cellis vero, sicut in coelis, ipsa veritate, ipso ordine, etsi nondum ipsa puritatis majestate, vel aeternitatis securitate, res ipsa omnium sacramentorum fidei nostrae assidue celebratur." 
at least one hour of the day to an attentive passing in review of the benefits conferred by his passion and redemption he wrought, in order to savour them in spirit and store them away faithfully in the memory. This is spiritually to eat the body of the Lord and drink his blood in remembrance of him. ${ }^{40}$

William explains that while only priests can preside over Holy Communion, the real substance of the sacrament can be celebrated by all believers who are a royal priesthood (cf. 1 Pet 2:9) in a spiritual sense: "The substance of the sacrament or mystery can be enacted and handled and received for salvation at all times in every place where God rules." ${ }^{41}$ William's inner liturgy is a constant one that is always accessible: "Now if you desire this, and if you truly desire it, this is at your disposal in your cell at all hours both of day and night. As often as you ... call to mind what he did when he suffered for you, you eat his body and drink his blood." ${ }^{2}$ William does not delve much into the fear of receiving sacramental communion, but does state that pure sacramental eating, without spiritual eating, brings death upon the communicant. But spiritual communion will always bear fruit: "The substance of the sacrament brings eternal life, even in the absence of the (visible) sacrament."43

Though William describes spiritual communion elaborately, he is not the only theologian who discusses this in the twelfth century. Other contemporaries who touch on this practice include Alger of Liège (d. 1131) and Hugh of St. Victor (ca. 1096-1144). Alger refers to two ways of partaking in the body of Christ: "the one physically, the other spiritually; one suits the mouth, the other the heart. ... With the heart we eat and drink in a spiritual manner."44 Hugh of St Victor, likewise, outlines the distinction between sacramental and spiritual communion. His theological positions influenced many

40) William of Saint-Thierry, The Golden Epistle, XXX.115. Cf. William of Saint-Thierry, "Epistola ad Fraters de Monte Dei (Epistola Aurea)," 327. "una saltem aliqua diei hora, passionis et redemptionis ipsius attentius recolere beneficia, ad fruendum suaviter in conscientia, et recondendum fideliter in memoria, quod est spiritualiter manducare corpus Christi, et bibere ejus sanguinem in memoriam ejus.”

41) William of Saint-Thierry, The Golden Epistle, XXX.117. Cf. William of Saint-Thierry, "Epistola ad Fraters de Monte Dei (Epistola Aurea)," 327. "rem vero sacramenti vel mysterii in omni tempore, et omni loco dominationis Dei ... agere, et tractare, et sumere sibi in salutem omnibus in promptu est."

42) William of Saint-Thierry, The Golden Epistle, XXX.119. Cf. William of Saint-Thierry, "Epistola ad Fraters de Monte Dei (Epistola Aurea)," 327. "Si autem vis, et vere vis, omnibus horis, tam diei quam noctis, hoc tibi in cella tua praesto est. Quoties in commemorationem ejus qui pro te passus est, hoc facto ejus pie ac fideliter fueris affectus, corpus ejus manducas, et sanguinem bibis"

43) William of Saint-Thierry, The Golden Epistle, XXX.118. Cf. William of Saint-Thierry, "Epistola ad Fraters de Monte Dei (Epistola Aurea)," 327. "res vero Sacramenti, etiam, praeter Sacramentum, sumenti vita aeterna est." Translation quoted with slight adaptations.

44) Alger of Liège, "De sacramentis corporis et sanguinis Domini," Patrologia Latina 180 (Paris: Migne, 1855), 797. "una corporalis, altera spiritualis ; una fit ore, altera fit corde. ... Corde vero spiritualiter comedimus et bibimus, quoties, ut ait beatus Augustinus, hoc quod pro salute nostra Filius Dei in cruce pependit in memoria recondimus." 
scholastic thinkers, including Bonaventure. ${ }^{45}$ As Hugh sees it, the substance of the sacrament consists in being incorporated by Christ. Yet, this incorporation can also take place through spiritual communion without sacramental communion:

He, who eats and is incorporated, has the sacrament and has the substance of the sacrament. He who eats and is not incorporated has the sacrament but not the substance of the sacrament. Just as he who is incorporated, even if he does not happen to eat, has the substance of the sacrament, although he has not the sacrament. He who takes has the sacrament, he who believes and loves has the substance of the sacrament. Therefore, it is better for him who believes and loves, even if he cannot take and eat, than for him who takes and eats and does not believe nor love, or if he believes but does not love. ${ }^{46}$

For Hugh of St. Victor, the substance of the sacrament is a spiritual union with Christ: "the invisible and spiritual participation with Jesus, which is being accomplished within the heart through faith and love." 47 Around the thirteenth century, this theme of mystical love for Christ in both sacramental and spiritual communion becomes more commonly accepted, and many female mystics refer to this as well.

\section{Mystics on spiritual communion in the thirteenth century}

Until 1200, most mystics of whom we have written records were monastic, male, and writing in Latin. From the thirteenth century onwards, mystical testimonies were also increasingly written by women and those outside traditional monasteries. Reasons for this development range from urbanization and the establishment of universities to growing literacy levels among the laity. Many wrote in the vernacular, thereby also developing new theological concepts and exploring new genres such as auto-

45) On the influence of Hugh of Saint-Victor, see Schlette, Die Lehre von der geistlichen Kommunion, 12-19.

46) Hugh of Saint-Victor, On the Sacraments of the Christian Faith, trans. Roy J. Deferrari (Eugene, OR: Wipf \& Stock Publishers, 2007), 307. Cf. Hugh of Saint Victor, De sacramentis christianae fidei, Patrologia Latina, vol. 176 (Paris: Migne), Book II.8.5, 465. "Qui manducat et incorporatur, sacramentum habet, et rem sacramenti habet. Qui manducat et non incorporatur, sacramentum habet, sed rem sacramenti non habet. Sicut qui incorporatur etiam si manducare non contingat, rem sacramenti habet quamvis sacramentum non habeat. Qui sumit sacramentum habet, qui credit et diligit, rem sacramenti habet. Melius ergo est illi qui credit et diligit, etiamsi sumere et manducare non possit, quam illi qui sumit et manducat et non credit, nec diligit; vel si credit non diligit."

47) Hugh of Saint Victor, On the Sacraments of the Christian Faith, 309. Cf. Hugh of Saint Victor, De sacramentis christianae fidei, Book II.8.7, 467. "et imago invisibilis et spiritualis participationis Jesu, quae intus in corde per fidem et dilectionem perficitur." 
biographical accounts and visions. ${ }^{48}$ This development is also reflected in the new testimonies on both sacramental and spiritual communion. Many women, beguines and Cistercians in particular, describe visions of meeting Christ in the Eucharist in a spiritual way, building on the anthropological notion that Christ dwells in the soul. The emphasis on spiritual union with Christ is so predominant that at times it is not easy to distinguish if an author describes spiritual or sacramental communion. The Cistercian Ida of Louvain describes a vision of her soul as a temple, in which Christ appears as a priest on the altar to perform the sacrifice on her inner altar. ${ }^{49}$ Hadewijch, a thirteenth-century beguine who also describes the soul as an abyss in which God dwells, was influenced by William's concept of spiritual communion. ${ }^{50}$ She envisions how Christ first gives himself to her in the shape of the Eucharist and, after that, gives himself to her in a full spiritual union:

Then he gave himself to me in the shape of the sacrament, in its outward form, as the custom is; and then he gave me to drink from the chalice, in form and taste, as the custom is. After that, he came himself to me, took me entirely in his arms, and pressed me to him..$^{51}$

One of the earliest personal testimonies on spiritual communion is found in the writings of the Benedictine nun Gertrude of Helfta (1256-1302). The nuns at Helfta engaged, like many other thirteenthcentury monastic women, in frequent sacramental communion. ${ }^{22}$ According to Gertrude, one can never receive communion too often. ${ }^{53}$ Though Gertrude also expresses fear of receiving the sacrament unworthily, she usually feels encouraged to partake in the sacrament. She experiences that her fear is taken away to the point that she feels like flying towards the altar. ${ }^{54}$ Gertrude's spiritual communion

48) Bernard McGinn, The Flowering of Mysticism. Men and Women in the New Mysticism 1200-1350, The Presence of God. A History of Western Christian Mysticism, vol. 3 (New York: Crossroad, 1998).

49) Ida of Louvain, "Vita Idae de Lovanio," in Acta Sanctorum, vol. Aprilis II, eds. Godefroid Henschen and Daniel van Papebroeck (Paris and Rome: Victor Palmé, 1866), 180.

50) On this, see, for example, Paul Verdeyen, "De invloed van Willem van Saint-Thierry op Hadewijch en Ruusbroec," Ons Geestelijk Erf 51 (1977): 3-19; Caspers, Eucharistische vroomheid, 39; Charles Caspers, "Late Medieval Liturgy," 383.

51) Hadewijch, The Complete Works, trans. Columbia Hart (Mahwah, NJ: Paulist Press, 1980), Vision 7. See Hadewijch, Visioenen vol. 1, Tekst en commentaar (Leuven, Gent, and Mechelen: De Vlaemsche Boekenhalle, 1924). "Doe gaf hi mi hem selven in specien des sacraments in figuren alsoe men pleghet. Ende daer na gaf hi mi drinken uten kelke, ghedane ende smake alsoe men pleghet. Dear na quam hi selve te mi ende nam mi alte male in sine arme ende dwanc mi ane heme."

52) Caspers, Eucharistische vroomheid, 38-41; Anna Harrison, “"I Am Wholly Your Own': Liturgical Piety and Community among the Nuns of Helfta," Church History 78, no. 3 (2009): 555.

53) Gertrude of Helfta, The Herald of Divine Love, trans. Margaret Winkworth (New York: Paulist Press, 1993), III.36.

54) For example, Book II chapters 7, chapter 20; Book III, chapters 6, 7, 10. Her desire to fly towards the altar is mentioned in Book III, chapter 10. 
is embedded in celebrating the liturgy inwardly. ${ }^{55}$ According to Gertrude, her soul is the throne of God where he dwells, and so his presence within enables her to experience the substance of the liturgy within. ${ }^{56}$ Her sacramental communion thus has an inner, spiritual parallel. She prays that she may have the "grace to offer the sacrifice on the altar of my heart." 57 She describes how at the moment of elevation "she was offering this same chalice as a thanksgiving to the Lord." 58 This spirituality also informs her concept of spiritual communion. Christ himself can celebrate the sacraments within her when she is not able to communicate sacramentally. Gertrude mentions that when she is unable to go to the sacrament of confession, Christ himself explains that He himself will renew all the sacraments within her, including the Eucharist:

I who am myself High Priest and true pontiff, I shall be ready to renew in your soul all seven sacraments at once, more effectively than any priest or bishop could do one at a time.... In my overflowing charity, I will feed you with myself, and will myself be refreshed by you. ${ }^{59}$

During the interdict on the monastery in 1296, the nuns were forbidden to receive the sacrament, though they could still watch the celebration, perhaps from a nun's gallery. ${ }^{60}$ Gertrude describes that she still received spiritual blessings while intensely watching the liturgical celebration. During the liturgy, Christ comforts her that this interdict and excommunication will not do any harm to her. She should consider it as a short time during which, for example, the Bridegroom takes aside his bride in private to rearrange a dress, so that afterwards she will come forward more gloriously in public. ${ }^{61}$ This enables her to participate spiritually in the sacramental celebration. During the elevation, Gertrude offers the host to God, in response to which the Lord gives himself to the community as spiritual food:

55) On this, see for example Michael Anthony Abril, "Gertrude of Helfta's Liturgical-Mystical Union," Cistercian Studies Quarterly 43, no. 1 (2008): 77-96; Vagaggini, Theological Dimensions of the Liturgy; Christoph Benke, “Mystik und Liturgie,” Zeitschrift für Katholische Theologie 125, no. 4 (2003): 451-54; Mary Forman, “Visions ‘Brimful of Love' During Christmas and Candlemas Liturgies in Gertrud of Helfta's Legatus II.16: A Study in Lectio Divina," Mystics Quarterly 32, nos. 3-4 (2006): 1-18.

56) Gertrude of Helfta, The Herald of Divine Love, Book I, chapter 5, 62.

57) Gertrude of Helfta, Book II, chapter 2, 96.

58) Gertrude of Helfta, Book III, chapter $5,159$.

59) Gertrude of Helfta, Book III, chapter 60, 225. Cf. Gertrude of Helfta, Insinuationes divinae pietatis (Cologne: Melchoir Novesiani, 1536).“Ego ipse summus sacerdos \& verus pontifex, tibi adero \& singulis vicibus simul septem sacramenta efficacius in anima tua renovabo, quam ullus sacerdos vel pontifex septem vicibus perficere posset. ... In supereffluentia charitatis meae te me ipso cibabo, teque fruendo satiabor."

60) This interdict is also mentioned by Mechtild in her Book of Special Grace, 3.16. The interdict was issued because of a dispute over a debt incurred by the monastery of Helfta. Cf. Gertrude of Helfta, The Herald of Divine Love, Book 2, chapter 16, footnote 25.

61) Gertrude of Helfta, The Herald of Divine Love, Book II, chapter 16. 
When she was offering this same host to the Lord ... the Lord himself received the host within himself, and then, breathing life-giving sweetness from his inmost being, said: With this breath I will feed them with divine food. Then she said to him: "Now, my Lord, are you giving communion to the whole community?" He replied: "No, but only to those who desire it or who would wish to have such a desire. ${ }^{62}$

Desire for sacramental communion is key to receiving the communion spiritually for Gertrude. For her, this spiritual communion is by no means inferior to sacramental communion, when one is not able to partake sacramentally, as was the case during the interdict or when she was ill. ${ }^{63}$

\section{Spiritual communion from the fourteenth to the sixteenth century}

From the fourteenth century onwards, spiritual communion became a much more widespread practice, and some authors state explicitly that spiritual communion is better than sacramental communion taken in an unworthy manner. Geert Grote, who founded the Modern Devotion movement, did not dare to receive sacramental communion regularly out of fear of partaking unworthily, and, for the same reasons, did not want to be ordained a priest. ${ }^{64}$ Nevertheless, many mystical texts focused on the harmony between spiritual and sacramental communion. The fourteenth-century mystic and Dominican preacher Johannes Tauler (1300-1363) testifies to regional differences, saying that in Cologne frequent sacramental communion was encouraged. ${ }^{65}$ Tauler also refers to the inner celebration of the liturgy in the soul, which is the perfection of the outer liturgy. His sermon on Church Dedication states that the liturgy of dedication in its true, full sense happens within the human person, without ceasing: "all modes and exercises of the Holy Church all point to the inner person, in whom the Church Dedication and renewal should truly take place without ceasing." ${ }^{66}$ Tauler applies this principle to the Eucha-

62) Gertrude of Helfta, Book III, chapter 16, 171. Cf. Helfta, Insinuationes divinae pietatis. "Cum illa eandem hostiam offerret domino ... dominus ipsam hostiam in semetipso suscipiens, \& ex intimis suis vivificam sauvitatem aspirans, dixit: ex hac aspiratione divina refectione saginabo eas. Hinc illa dixit ad dominum: Num domine mi, nunc communicas omnem congreationem? Qui respondit: Non, sed tantummodo desiderium habentes \& eas quae vellent habere desiderium."

63) Her spiritual communion during illness is described in Gertrude of Helfta, The Herald of Divine Love, Book II, chapter 18, 119.

64) Charles Caspers, "Late Medieval Liturgy," 386

65) Johannes Tauler, Sermons, trans. Maria Shrady, The Classics of Western Spirituality (New York: Paulist, 1985), Corpus Christi IV, 110.

66) Johannes Tauler, Sermons de J. Tauler et autres écrits mystiques. 2: Le Codex Vindobonensis 2739 (Liège: Vaillant-Carmanne, 1929). Tauler II, sermon 19, 219: “alle wise und übunge der heiliger kirchen die wiset allit uf den inwendigen menschen, da in der warheit kirwigen und eyne war virneygunge [editor's comment: virnyjunge] sulde sin ane underlaz." 
rist. He maintains that spiritual communion is better than taking the sacrament unworthily, as Judas did, a theme mentioned earlier in Augustine and William of Saint-Thierry. In spiritual communion, one receives the benefits of the sacrament according to the measure of one's desire, which can sometimes be even more than those who receive sacramental communion:

And there are those who receive it spiritually, without actual sacramental communion, good people, pure in heart, who long for the Blessed Sacrament, but to whom it cannot be given at the time. These latter perhaps receive the grace of the sacrament in a higher degree, in proportion to their desire and disposition, than those who receive it sacramentally. ${ }^{67}$

For Tauler, spiritual communion is a spiritually profitable practice, even though in the same sermon he also encourages his hearers to receive sacramental communion whenever possible. This approach also echoes through the widely read Imitation of Christ. Thomas à Kempis (1380-1471) exhorts his readers to partake in the sacramental communion as often as one can. In fact, his whole book can be read as an exhortation to eat the sacrament to one's spiritual benefit. ${ }^{68}$ Though one should not abstain from sacramental communion, spiritual communion is an equal alternative to those who are prevented by good reasons from participating: ${ }^{69}$

67) Tauler, Sermons, Corpus Christi IV, 110. Cf. Predigt 33 (Caro mea vere est cibus), Johannes Tauler, “Die Predigten Taulers. Aus der Engelberger und der Freiburger Handschrift sowie aus Schmidts Abschriften der ehemaligen Straßburger Handschriften hrsg. von Ferdinand Vetter (DTM 11), Berlin 1910 (Nachdruck Dublin/ Zürich 1968). Elektronischer Text und Konzeptausdruck hergestellt für das Digitale Mittelhochdeutsche Textarchiv und das Mittelhochdeutsche Wörterbuch," http://www.mhdwb-online.de/Etexte/PDF/TAULER.pdf (2020). "Die vierden die nement diz sacramente geistlichent, sunder sacramente; das sint gůte luterre hertzen die dis heilgen sacramentes begerent und in nút also zů der zit werden enmag; die enpfohent die genade des sacramentes villiht me denne die es sacramentlichen enpfohent, darnoch das ir begerunge und ir meinunge ist."

68) Charles Caspers, "The Sacrament of the Eucharist and the Conversion of Geert Grote," in Diligens scrutator sacri eloquii. Beiträge zur Exegese- und Theologiegeschichte des Mittelalters. Festschrift Rainer Berndt, eds. Hanns Peter Neuheuser et al. (Münster: Aschendorff, 2016), 523.

69) Thomas à Kempis, The Imitation of Christ. A New Reading of the 1441 Latin Autograph, trans. William C. Creasy (Macon, GE: Mercer University Press, 2007), Book 4, chapter 10. Translation quoted with slight adaptations. Thomas à Kempis, De Imitatione Christi. Liber Quattuor multiplici lingua nunc primo impresso, ed. Johannes B. Weigl (Solisbaci: Seidel, 1837). “Cum vero legitime praepeditus est, habebit semper bonam voluntatem, et piam intentionem communicandi, et sic non carebit fructu sacramenti. Potest enim quilibet devotus omni die et onmi hora, ad spiritualem Christi communionem salubriter, et sine prohibitione accedere. Et tamen certis diebus et statuto tempore Corpus sui Redemptoris, cum affectuosa reverentia sacramentaliter debet suscipere. ... Nam toties mystice communicat, et invisibiliter reficitur, quoties incarnationes Christi mysterium passionemque devote recolit, et in amorem eius accenditur." 
When he is honestly prevented from Holy Communion, however, let him always have a good will and the holy intention of sharing in the body and blood of Christ; and in this way, he will not miss the benefit of the sacrament. For every day and every hour any devout person can freely come to the spiritual communion with Christ. Nevertheless, on certain days and at appointed times he ought to receive sacramentally.... As often as a person meditates on the mystery of Christ's Incarnation and Passion, so often does he communicate with him in a mystical way and so often is he refreshed by Christ and enflamed with love for him.

For Thomas, spiritual communion spiritually nourishes the believer.

This practice of spiritual communion still flourished in the sixteenth century before the Council of Trent emphasized the need for sacramental communion. ${ }^{70}$ Three anonymous mystical texts from the Low Countries, the Evangelical Pearl (1537/1538), the Temple of Our Soul (1543), and the Arnhem mystical sermons (ca. 1545) refer to the inner celebration of the liturgy and the celebration of the sacrament within. Because these texts focus on union with Christ, the boundaries between spiritual and sacramental communion merge. ${ }^{71}$ Likely influenced by Tauler, who was widely read in the Low Countries, these three authors define the inner celebration of the liturgy and the sacrament. Spiritual communion is one aspect of that which the liturgy ultimately points to and finds its fulfillment in: the ceaseless celebration of the liturgy within the person. The outer celebrations point to the substance of the liturgy, which is celebrated inwardly. The author of the Pearl explains that Christ's feasts should be celebrated inwardly: ${ }^{72}$

All the other great feasts that were outwardly celebrated by me [= Jesus Christ] should also be fulfilled spiritually within you, for which reason they should be celebrated, since you should constantly have and carry in your heart my whole life.

70) On this process, see Caspers, Eucharistische vroomheid, 221-22. For the Council of Trent on the sacrament, see Session XIII (1551) and XXII (1572) in Denzinger and Schönmetzer, Enchiridion Symbolorum, 87393; 937-56.

71) On the relationship between these texts, see chapter three of Ineke Cornet, The Arnhem Mystical Sermons. Preaching Liturgical Mysticism in the Context of Catholic Reform (Leiden: Brill, 2018). See also Rob Faesen, "The Three Births of Christ and the Christmas Liturgy in the Temple of Our Soul, the Evangelical Pearl and the Arnhem Mystical Sermons," Ons Geestelijk Erf 81, no. 1 (2010): 121-37.

72) “The Evangelical Pearl, Part III," trans. Helen Rolfson, in Late Medieval Mysticism of the Low Countries, eds. Rik Van Nieuwenhove, Robert Faesen, and Helen Rolfson, The Classics of Western Spirituality (New York: Paulist Press, 2008), 222-23. See Die grote evangelische peerle, vol devoter gebeden, godlijcker oeffeninghen ende geesteliker leeringhen, ed. Theodoricus Loer (Antwerp: Henrick Peetersen van Middelburch, 1537). III.3: "Ende so voort dat alle andere hoochtijden, dye uutwendelic van my begaen werden, ooc gheestelic in u volbracht mogen worden; daer si al om geviert werden, om dat ghi al mijn leven ... stadelic in uwer herten sult hebben ende dragen." 
The author of the Pearl connects Christ's life with both the outward celebration in the Church and the inner celebration. The liturgy finds its fulfilment in the inner celebration where Christ is present within the person. The recollection of what Christ did is also central to spiritual communion. In a chapter dedicated to both sacramental and spiritual communion, the author writes that spiritual communion should take place frequently so that Christ may abide with us: "We shall desire to receive this frequently throughout the day and the night so that we may be transformed into a life of grace, so our spirit may remain in God's presence through his joyous spirit."73 The way to receive communion spiritually is to be aware of God's continual sacrificial love for the person and to offer oneself back to God:

"This is my body ... and my blood." So offer yourself back into the love with which He gave himself into the hands of his enemies for our sake.... In this love I desire to live and die.... O, what a noble goodness we have in ourselves, who nobly feeds our soul and lovingly embraces it and transforms it into him and never ceases to feed us by night and day with the divine influx of his spirit - for which reason we should frequently offer ourselves back [to him] as a sacrifice of praise - united in love, while bringing our spirit into his presence with love. ${ }^{74}$

Because God dwells within, the person can always spiritually receive the love of God and love Him through spiritual communion.

The author of the Temple of Our Soul focuses on how the liturgy in the temple is reflected in the temple of the soul. She outlines that the inner liturgy can take place ceaselessly within the person: "A person who exercises the virtues always has a high feast in himself." 75 As God dwells in the spirit of the person, his presence enables the inward celebration of the liturgy. ${ }^{76}$ The liturgy is celebrated for the sake of this inner liturgy: "The exterior temple is made for this inner temple. Everything that is dis-

73) Die grote evangelische peerle, I.18. "Daer om sullen wi dat dick begeren te ontfangen door den dach ende inder nacht, op dat wij daer door verwandelt mochten werden in een leven der gracien, op dat door biwesen zijns vrooliken geests onsen geest bliven mach in gods tegenwoordicheit."

74) Die grote evangelische peerle, I.18. "Dat is mijn lichaem, dat voor u ghegheven sal werden ende mijn bloet, dat voor u ghestort sal werden. So offert u selven weder in dier liefden daer hi hem selven in gaf om onsen wille inde handen zijnre vianden.... In dier selver liefden begeer ic te leven ende te sterven.... Och want wi nu aldus edelen goet in ons hebben, die onse siele so edelic spijset ende so lieflicken ombevanget ende in hem verwandelt ende en hout niet op nacht ende dach ons te spijsen met zijn godlike ingeesten. Hier om sullen wi dick ons selven weder offeren in een offerhande des lofs in vereeninge der minnen met minlike toegeesten."

75) “The Temple of Our Soul (extracts)," trans. Robert Faesen, in Late Medieval Mysticism of the Low Countries, eds. Rik Van Nieuwenhove, Robert Faesen, and Helen Rolfson, The Classics of Western Spirituality (New York: Paulist Press, 2008), 328. Cf. Den tempel onser sielen. Door de schrijfster der Evangelische Peerle, ed. Albert Ampe, vol. 18 (Antwerpen: Ruusbroecgenootschap, 1968), Chapter 8, II. 7-8. "Mer een oeffenaer der duechden heeft altijt een feestdach in hem."

76) See also M. Smits van Waesberghe, "Liturgie und Mystische Gottesbegegnung im altniederländischen Traktat ‘Den Tempel Onser Sielen,”' Zeitschrift für Katholische Theologie 91, no. 3 (1969): 501-506. 
posed in it has no purpose other than to come to this inner temple, and all that is celebrated in it has no aim other than to be perfected in this inner temple."77 This is applied to the sacraments as well:

In that one [the exterior temple] the sacraments are given and received through human efforts, but in this one [the interior temple] they are given, served, and received by God himself, who has become for us a blessed offering. In that one high feasts are celebrated and pass away, but in this one they are celebrated and remain in the essence of the soul. ${ }^{78}$

Thus, God himself celebrates the sacraments in the innermost of the person. The author describes how the feast of Corpus Christi should take place incessantly in the ground of the soul. This is the feast where Christ gives himself as food and drink, through which we are enflamed in love. ${ }^{79}$ Here, the difference between sacramental and spiritual communion is not spelled out. The author focuses so much on union with Christ that sacramental and spiritual communion are tied together in one harmonious flow. Ultimately, the sacrifice of the Eucharist is celebrated continually within the person. The soul is

a temple of the Holy Trinity, in which the divine liturgy and the sacrifice are celebrated without ceasing. The high feasts remain there forever essentially, and do not pass away. There is always a high feast because of God's indwelling. ... There, all the high feasts have their beginning and origin, there they will remain and find their perfection: the soul carries it all in her, because she has God within her. ${ }^{80}$

Thus, for these sixteenth-century mystical texts, God's indwelling within is foundational for the inner celebration of the liturgy, which also encompasses spiritual communion. The inner celebration is the fulfilment of that which the liturgy and sacraments points to and takes place continuously within the person. Christ's presence in both the liturgy and within allows these authors to intertwine sacramental

77) “The Temple of Our Soul (extracts)," chapter 8, 329. Den tempel onser sielen, chapter 8, II. 38-41. "Om desen inwendigen tempel is desen uutwendigen tempel ghemaect; ende al dat daerin is gheordineert, en is anders niet dan te comen tot desen inwendigen tempel, al hetghene datmen daerin begheert, dattet al in desen inwendigen tempel volbracht soude werden."

78) “The Temple of Our Soul (extracts)," Chapter 8, 329-330. Den tempel onser sielen, chapter 8, II. 58-63. "In dien werden die sacramenten ghedient ende ghegeven van menscheliken dienst; mer in desen werden si van God selver ghegeven, ghedient ende ontfangen, die voor ons selver een salige offerhande is gheworden. In dyen tempel werden die hoochtiden gheviert, ende hebben een voorbigaen; mer in desen werden die gheviert ende bliven daer weselic."

79) Den tempel onser sielen, chapter 51.

80) Den tempel onser sielen, chapter 53. "een tempel der heyliger Drievuldichteit, daer den godliken dienst ende sacrificie stadelijc in gheoeffent wort, daer die hoochtiden weselic in bliven, ende gheen voorbigaen en hebben, ende altijt hoochtijtlike feeste is overmits dat inwonen Gods. ... Daer alle dese hoochtiden haer beghinne ende haren oorspronck uut hebben ende in bliven ende eynden: dit draecht die siele altemael in haer, want si en God in haer heeft." Translation mine. 
and spiritual communion. After the Council of Trent's decisions diffuse, however, the practice of spiritual communion declines, and it is no longer referred to in mystical texts.

\section{Conclusion}

The practice of spiritual communion builds on the tradition that defines spiritual union with Christ as central to sacramental communion. During the high Middle Ages, this spiritual communion came to be seen as a spiritual practice that could also be experienced without and outside the moment of sacramental communion. For mystics, however, spiritual communion was never pitted against sacramental communion. Medieval mystics share a high view of the sacrament, which is intrinsically connected with deepening spiritual union with God. Nevertheless, this inner union with Christ could also be obtained without the sacrament. The starting point is the distinction between the sacrament as such and the substance of the sacrament, which is, in the mystical tradition, defined as a spiritual union with Christ through faith and love. This substance of the sacrament can also be obtained without the sacrament, if one is hindered from sacramental communion. As Christ dwells within, the substance of the sacrament is performed by him within the person. He thus 'performs' everything the sacrament points to. This spiritual communion happens either through watching the Eucharistic celebration or through an inner meditation on the matter of the sacrament. The mystics agree that spiritual communion enables one to participate in the celebration of Christ's mysteries in a way not inferior to sacramental communion. This is always true when one is hindered from sacramental communion. But the practice of spiritual communion goes deeper. The mysteries celebrated in the liturgy are also perceived as an invitation to celebrate these mysteries inwardly, spiritually, and continually. This is the continuous spiritual communion that can also take place through meditation on Christ's redemptive suffering. The inner liturgy and inner (spiritual) communion are not opposed to the exterior liturgy and sacramental communion, but are extensions of this into the person's life. The spiritual union with Christ ties together both the spiritual and sacramental communion, as one communicates with Him sacramentally and continues to do so before and after a sacramental celebration through spiritual communion.

As we reflect on the Eucharist during a pandemic, I suggest that we appreciate again this inner, spiritual participation in the liturgy if we cannot physically attend the Eucharist. Perhaps this is perceived as difficult because our culture puts more emphasis on active participation in the liturgy, while the mystics point much more to actual, engaged celebration of the liturgy, in which the spiritual way is no less real than the physical, active way. ${ }^{81}$ Although it is beyond the scope of this article to delve into the arguments for and against celebrating the Eucharist online, the rich tradition of spiritual communion is certainly worth taking into account, not only as a replacement for sacramental communion

81) On this understanding of participation actuosa, see Ad de Keyzer, “'Participatio actuosa'. Een droom die onvervuld blijft?” in Christelijke initiatie en de liturgie. Hulde aan professor dr. Jozef Lamberts bij zijn emeritaat (Leuven: Peeters, 2006), 211-24. 
if one is hindered, but also as a practice that connects sacramental communion deeper with one's spiritual life.

Ineke Cornet obtained her PhD (2011) in Theology from the Catholic University Leuven and her PhD of Arts in Literature from the University of Antwerp. She is the author of the first monograph on the Arnhem mystical sermons, entitled The Arnhem Mystical Sermons: Preaching Liturgical Mysticism in the Context of Catholic Reform (Brill, 2019). Her main research interest is the liturgical dimension of late medieval mysticism. She lectures in the history of Spirituality at the University of Divinity in Melbourne, Australia, and is a postdoctoral research fellow at the Titus Brandsma Institute at the Radboud University Nijmegen.

Email: ineke.cornet@titusbrandsmainstituut.nl 